
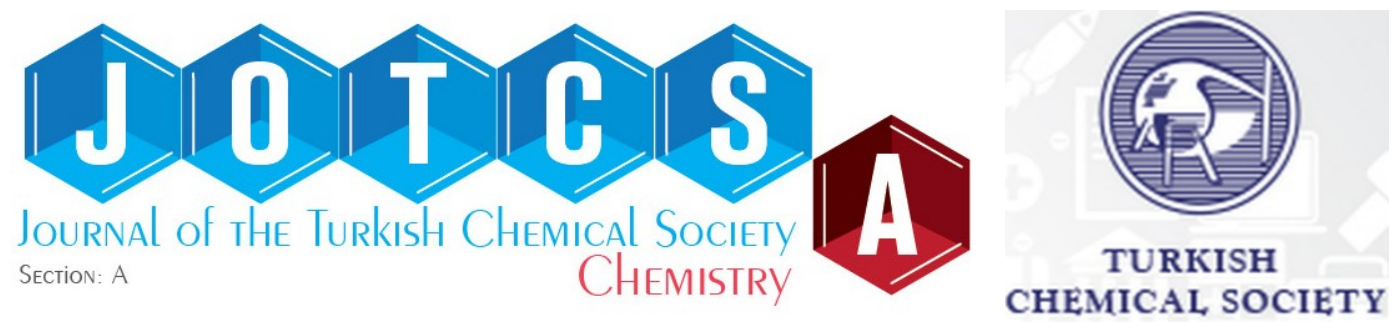

\title{
Phytochemical Screening and Antibacterial Activity of Pistacia atlantica and Pinus canariensis Leaf Extracts
}

\author{
Obaida ALHAJALI* $\triangle D$ and Adnan ALI-NIZAM $\square$ \\ Damascus University, Faculty of Science, Damascus, Syria
}

\begin{abstract}
The qualitative detection of phytochemical compounds of extracts was carried out using color reagents, total content of phenols and flavonoids was specified using Folin-Ciocalteu and aluminum chloride method, respectively, and antioxidant activity was determined through its ability to free radicals scavenging using DPPH radical. The efficacy of the plant extracts against pathogenic bacteria was studied by agar well diffusion method with different concentrations, and microdilution method was used to measure minimum inhibitory concentration (MIC) of all plant extracts. The results showed presence of tannins, phenols, and flavonoids in all extracts of both plants, while saponins were found in aqueous extracts only, cardiac glycosides and coumarins were absent in all plant extracts. Ethanolic extract of Pistacia atlantica recorded the highest content of phenols and flavonoids as $263.76 \pm 0.53$ (mg GAE/g Dw) and $46.83 \pm 0.55$ (mg RE/g Dw), respectively. While aqueous extract of Pinus canariensis recorded the lowest content of of phenols and flavonoids $30.11 \pm 0.37$ (mg GAE/g Dw) and $5.43 \pm 0.38$ (mg RE/g Dw), respectively. Both plants have been shown to have good antioxidant activity, as ethanolic extract of P. atlantica recorded the best ability to free radicals scavenging $90.27 \% \pm 1.51$, ethanolic extracts of both plants were the most effective in inhibiting bacteria especially at high concentrations $(500 \mathrm{mg} / \mathrm{mL})$; the inhibition zone diameter of $P$. atlantica extract reached $33.56 \mathrm{~mm}$ against Shigella boydii, while aqueous extract of $P$. canariensis was the most effective against Pseudomonas aeruginosa; the inhibition zone diameter was $21 \mathrm{~mm}$. MIC ranged between 5.468 and $43.75 \mathrm{mg} / \mathrm{mL}$ depending on plant extract and bacterial species. This confirms the importance of plant extracts as a natural source of antibacterial to confront problems of increasing bacterial resistance to antibiotics that threaten public health.
\end{abstract}

Keywords: Total phenolic, flavonoid, DPPH, antibacterial activity, MIC value, Pistacia atlantica, Pinus canariensis.

Submitted: December 04, 2020. Accepted: February 06, 2021.

Cite this: ALHAJALI O, ALI-NIZAM A. Phytochemical Screening and Antibacterial Activity of Pistacia atlantica and Pinus canariensis Leaf Extracts. JOTCSA. 2021;8(2):403-18.

DOI: https://doi.org/10.18596/jotcsa.836074.

*Corresponding author. E-mail: obaida.alhajali20@gmail.com.

\section{INTRODUCTION}

Plants have shown an important role in treating and preventing many diseases in pharmacology since past time, and plant extracts were used to treat various diseases such as diarrhea, sleep disorders and cough, infections, cancer, cardiovascular, and diabetes, due to their wide spread and diversity, and they contain many compounds with therapeutic characteristics. In addition, medicinal plants have been shown to possess the advantage of having low side effects compared to antibiotics $(1,2)$. About $80 \%$ of the world's population depends on traditional medicine according to WHO estimates. As a result, the demands of plant extracts for medicinal purposes in many countries had been increased (3). It was focused on that secondary metabolites in medicinal plants are characterized with different medicinal properties. On the other hand, detection of genes of Staphylococci maintained increasing antibiotic resistance as well as: amoxicillin/ clavulanic acid $65 \%$, ampicillin $70 \%$. Percentage of presence of MRSA strains was $15 \%$ and MRCNS was $6.66 \%$ (4). Occurrence of bacterial multidrug resistance feature side effects of medicine use induced WHO to maintaining importance of plants therapy (5). The random use of antibiotics used to treat diseases sometimes led to negative side effects on the host as immune response, allergic reactions, 
and hypersensitivity, which necessitated to develop alternative drugs from different sources such as plants (6). A positive effect of Myrtus communis extracts occurred against pathogenic bacteria (7), and the effect of Lamiaceae plants extracts as Mentha and Ocimum; which induce to isolate and study phytochemicals for explaining its effects against microorganisms (8).

Pistacia atlantica (Anacardiaceae) is a tree with a length of 2-5 m, its branches are grayish-white and have leaves composed of 9 to 11 leaflets (pinnate compound leaves). Oleoresin is secreted by the trunk featuring a yellowish-green color and a mild smell (9), and it contains many chemical compounds in various parts of the plant: $\alpha$-pinene, limonene, $\beta$-pinene, terpinolene, camphene, bornyl acetate, sabinene, p-mentha-1 (7),8 diene, $\Delta^{3}$ carene, spathulenol, masticadienonic acid, morolic acid, gallic acid, oleanolic acid, tetragalloylquinic acid, quinic acid, quercetin-3-glucoside, 3-O-acetyl3-epiisomasticadienolic acid

methoxycarpachromene, $\beta$-myrcene, $(9,10,11)$. P atlantica has antibacterial activity, as a research has indicated that it has widespread inhibitory effects against number of Gram (-) bacteria ( $E$. coli, Proteus mirabilis, Pseudomonas aeruginosa, Enterobacter cloacea, Salmonella typhi, Acinetobacter baumannii) and Gram (+) (Staphylococcus aureus, Listeria monocytogenes) $(12,13)$, and antifungal properties against some microorganisms (Aspergillus fumigates, Aspergillus flavus, Aspergillus niger, Candida sp) (14), and anti-adenovirus agent (15), and anti-inflammatory activity (16).

Pinus canariensis (Pinaceae) is an evergreen tree reaches more than $30 \mathrm{~m}$ high, resin canals in wood, bark, leaves and often cones, Dwarf shoots (fascicles) hold three long $(20-30 \mathrm{~cm})$ needles (17). Analysis of the essential oil showed 116 compounds; more than 100 substances belonging to terpenoids: (sesquiterpenes, monoterpenes, and diterpenes) by $52.1 \%, 42.7 \%$, and $4.8 \%$ respectively, the most important substances of monoterpenes are ( $\alpha$-pinene $23.1 \%, \beta$ - pinene $1.6 \%$, myrcene $5.8 \%$, limonene $10.1 \%$ ) (18). Another study showed the presence of monoterpenes $30.7 \%$, the most important of which were ( $\alpha$ - pinene $14.6 \%, \beta$ - pinene $1.2 \%$, myrcene $6.4 \%$, and limonene $7.9 \%$ ), and sesquiterpenes $66.6 \%$, (as germacrene $D$ formed the main compound $44 \%$, then $\beta$-caryophyllene $8.7 \%$ ), and diterpenes $2.4 \%$ (19). Pinus in traditional medicine are used for respiratory system as antiseptic and expectorant, also for gastrointestinal disorders, urinary system diseases and for the treatment of skin diseases. Pine needles extracts showed effect against a range of bacteria as (Staphylococcus aureus, Escherichia coli, Pseudomonas aeruginosa, and Bacillus cereus) (20) pine needles showed exhibit strong antioxidant, antimutagenic and also antitumor effects in vivo and point to their potential usefulness in cancer prevention (21).
The increase in the infectious diseases and the development of bacterial resistance to antibiotics, and their side effects necessitate search for new compounds that are effective against pathogenic bacteria. This research aims qualitative (alkaloids, cardiac glycosides, resins, tannins, flavonoids, saponins, phenols, and coumarins) and quantitative screening (total phenolic and flavonoid contents), and study of antioxidant activity of Pistacia atlantica and Pinus canariensis leaf extracts, and testing their bioactivity against pathogenic bacteria.

\section{MATERIALS AND METHODS}

\section{Collection of Samples}

Samples of Pistacia atlantica and Pinus canariensis leaves were collected in Sweida area (Syria) in September of 2019, and washed with distilled water to remove impurities, and dried in shadow for 14 days, and ground into a dry soft powder, and powders were stored in refrigerator at $4{ }^{\circ} \mathrm{C}$ until use (13).

\section{Preparation of Extracts}

Aqueous and ethanolic extracts were prepared using Soxhlet method; 50 grams of powdered leaves were separately extracted in $500 \mathrm{~mL}$ of water and ethanol at a ratio $1: 10(w / v)$ for $7 \mathrm{~h}$, and filtered using Whatman filter paper №1. Filtrates were evaporated using a rotary evaporator under vacuum at $40{ }^{\circ} \mathrm{C}$ and kept in refrigerator at $4{ }^{\circ} \mathrm{C}$ until they were used (22). All extracts were sterilized before use by filtration through membrane filters $0.45 \mu \mathrm{m}$. Determination of percentage yield (\%) was calculated using the formula (23):

$$
\begin{gathered}
\text { yield } \%=\text { (weight of final dried extract / weight of } \\
\text { initial dried plant sample }) \times 100
\end{gathered}
$$

\section{Phytochemical Qualitative Screening Test}

Test for Alkaloids

a-Dragendorff's reagent test: A few drops of Dragendorff's reagent were added to (1 $\mathrm{mL})$ of each extracts and mixed, then diluted hydrochloric acid $(2 \mathrm{~mL})(\mathrm{HCl})$ were added. formation of precipitate of reddish-yellow color indicates appearance of alkaloids.

b- Mayer's test: To each $1 \mathrm{~mL}$ of studied extracts a few drops of Meyer's reagent were added. Formation of a creamy white precipitate indicates appearance of alkaloids (24).

\section{Test of Cardiac glycosides}

Keller Killiani Test: $1 \mathrm{~mL}$ of anhydrous acetic acid added to each extract of plant and shaken, then a few drops of ferric chloride were added, and 2-3 drops of sulfuric acid (concentrated) were added carefully to the test tube, appearance of a reddishbrown-colored ring at the junction of two layers, which confirms the positive test $(24,25)$. 
Test for Resins

Turbidity test: $10 \mathrm{~mL}$ of distilled water was added to each plant extract, to which a few drops of $4 \%$ $\mathrm{HCl}$ were added. Appearance of turbidity in solution indicates presence of resins (25).

\section{Test of Tannins}

Lead acetate Test: A few drops of lead acetate were added to $1 \mathrm{~mL}$ of plant extract. Formation of a large white-brown precipitate indicates presence of tannins (24).

\section{Tests for Flavonoids}

a- Shinoda Test: $0.5 \mathrm{~g}$ of magnesium powder was added to each plant extract, then a few drops of concentrated hydrochloric acid were added. Appearance of a red color indicates presence of flavonoids.

b- Alkaline Test: Sodium hydroxide solution was added to 1-2 $\mathrm{mL}$ of each plant extract. A yellow to red color formed in test tube confirms presence of flavonoids $(24,25,26)$.

\section{Test for Saponins}

One $\mathrm{mL}$ of plant extract was added to $20 \mathrm{~mL}$ of distilled water, and shaken vigorously for 5-10 minutes. Formation of a froth column that does not disappear by adding $\mathrm{HCl}$ indicates presence of saponins $(25,26,27)$.
Test for Phenols

To each plant extract was added $1 \mathrm{~mL}$ of $\mathrm{FeCl}_{3}$ (5\%). Formation of bluish-black color indicates presence of phenols (25).

\section{Test for Coumarins}

One $\mathrm{mL}$ of each extract were taken in separate tubes, and covered with a filter paper moistened with $1 \mathrm{~N} \mathrm{NaOH}$ solution, and heated for a few minutes. When these tubes yield a yellow fluorescence under UV light, this indicates the presence of coumarins (24).

\section{Phytochemical Quantitative Screening Test}

Total phenolic content (TPC)

TPC in all plant extracts were measured by the Folin-Ciocalteu method, $1000 \mu \mathrm{L}$ of each sample of concentration of $0.011 \mathrm{~g} / \mathrm{mL}$ was added to $4.8 \mathrm{~mL}$ distilled water, $4 \mathrm{~mL}$ sodium carbonate $2 \%$ $\left(\mathrm{Na}_{2} \mathrm{CO}_{3}\right)$ and $200 \mu \mathrm{L}$ of Folin- Ciocalteu reagent and mixed fully, the absorbance was recorded at $760 \mathrm{~nm}$ by a spectrophotometer after $60 \mathrm{~min}$ of incubation, distilled water was used as a blank. A calibration curve of gallic acid solutions were prepared in ethanol at different concentrations 0 to 300 ppm (Figure 1), and the results were estimated as gallic acid equivalent for each gram of dry plant extract (mg GAE/g Dw). Total phenolic contents of samples were determined in triplicate $(28,29)$.

Gallic acid

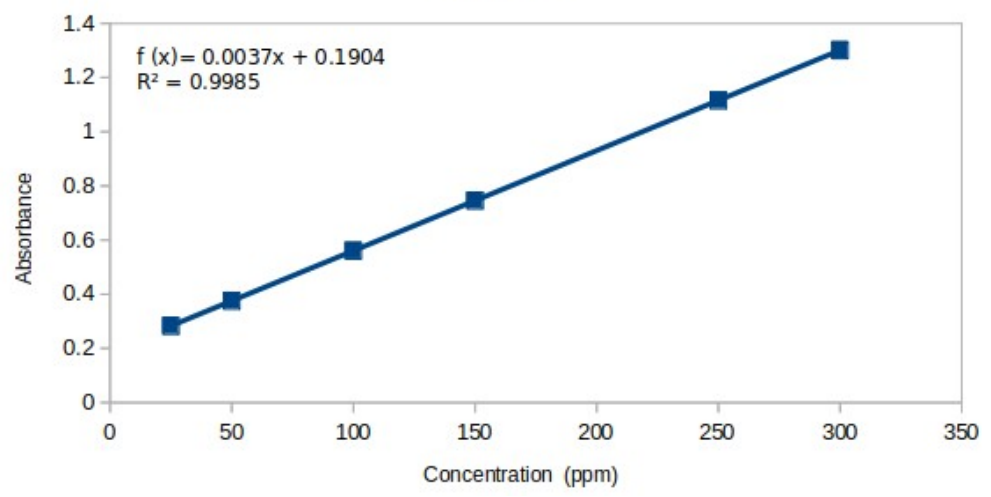

Figure 1. Calibration curve of gallic acid.

\section{Total Flavonoid content (TFC)}

TFC was measured using aluminum chloride method $\mathrm{AlCl}_{3}, 6 \mathrm{H}_{2} \mathrm{O}$ in the plant extracts, each plant extract $(0.5 \mathrm{~mL})$ was added to distilled water (2 $\mathrm{mL}$ ) and $150 \mu \mathrm{L}$ of sodium nitrite $\mathrm{NaNO}_{2}(5 \% \mathrm{w} / \mathrm{v})$. After 5 minutes, $10 \%$ of aluminum chloride solution (150 $\mu \mathrm{L})$ was added to mixture, then incubated in the dark for $6 \mathrm{~min}$. Finally, $4 \%$ of $\mathrm{NaOH}(2 \mathrm{~mL})$ was added and mixed well, after 15 minutes of incubation in the dark the solutions turned to pink. Distilled water was used as a blank, the absorbance was recorded at $510 \mathrm{~nm}$ by a spectrophotometer, a calibration curve of rutin solutions were prepared at different concentrations 0 to $150 \mathrm{ppm}$ (Figure 2), and the results were estimated as rutin equivalent per gram of dry plant extract (mg RE/g Dw). Total flavonoid of samples were measured in triplicate (30). 


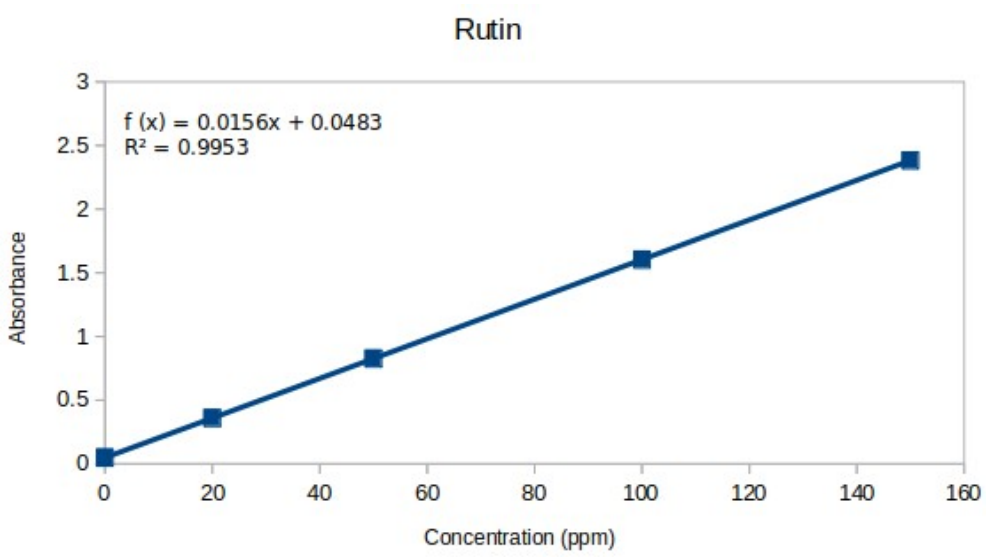

Figure 2. Calibration curve of rutin.

\section{Antioxidant Activity}

DPPH Radical Scavenging Activity Assay

Each plant extract $(300 \mu \mathrm{L})$ of concentration of $0.001 \mathrm{~g} / \mathrm{mL}$ was added in test tubes separately, and $3 \mathrm{~mL}$ of DPPH in ethanol $(45 \mu \mathrm{g} / \mathrm{mL})$ was added to each tube and mixed vigorously, after 30 min of incubation without light the absorbance was recorded at $515 \mathrm{~nm}$ by a spectrophotometer. The results were presented compared to ascorbic acid which was prepared as standard with different concentrations from 0 to $0.5 \mathrm{mM} / \mathrm{L}$ (Figure 3 ). The results were calculated as a percentage (\%) using the following formula (31):

Scavenging DPPH $(\%)=A_{\text {control }}-A_{\text {sample }} / A_{\text {control }} \times 100$

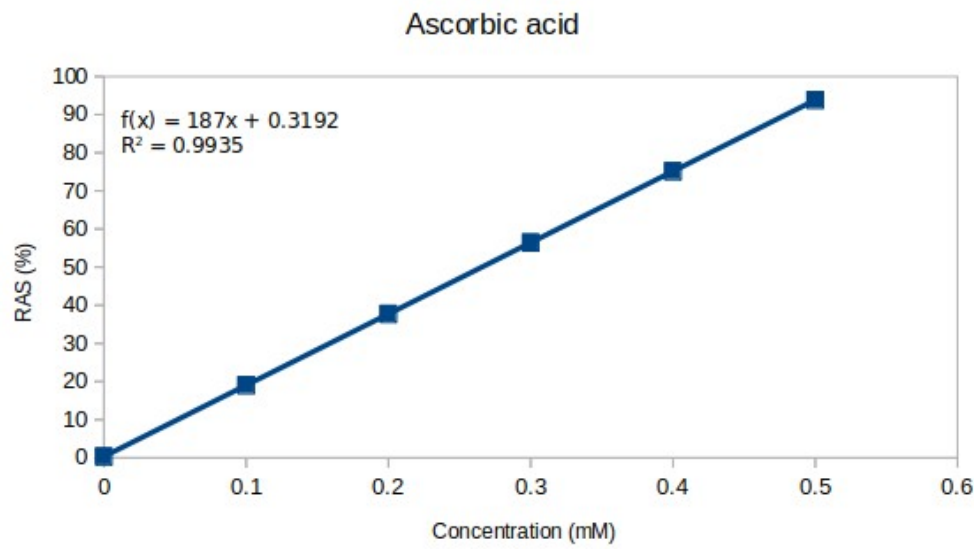

Figure 3. Calibration curve of ascorbic acid.

\section{Antibacterial Susceptibility Test}

\section{Bacterial Isolates}

The antibacterial test was carried out using: Staphylococcus aureus, Klebsiella pneumoniae, E. coli, Proteus mirabilis, Pseudomonas aeruginosa, Shigella boydii, and Enterobacter cloacae, were obtained from the microbiology Laboratory Department of Plant Biology, Faculty of Science at the university of Damascus (Syria).

\section{Antibacterial Activity}

The bacterial susceptibility tests for plant extracts were performed by agar well diffusion method on Mueller-Hinton agar. The bacterial isolates were activated for $24 \mathrm{~h}$ at $37{ }^{\circ} \mathrm{C}$ on nutrient agar, then a bacterial suspension was prepared in a saline solution [sterile $\mathrm{NaCl} 0.85 \%(w / v)$ ]. Turbidity of prepared bacterial suspension was 0.5 McFarland $\left(10^{8} \mathrm{CFU} / \mathrm{mL}\right)$. The suspension was used to inoculate $9-\mathrm{cm}$-diameter Petri dishes with a sterile cotton swab, after that 5-6 wells (4 mm diameter) were punched in the agar plate, and $50 \mu \mathrm{L}$ of plant extracts were added in each well. All plates were placed in the refrigerator $\left(4^{\circ} \mathrm{C}\right)$ for $2 \mathrm{~h}$ in order to allow diffusion of plant extracts into the medium. Then the plates were incubated for $24 \mathrm{~h}$ at $37^{\circ} \mathrm{C}$. After incubation, inhibition zone diameters were measured to determine the effectiveness of extracts against tested bacteria. Tests were performed in triplicates per experiment and the average of the results was taken, the plant extracts were dissolved in dimethyl sulfoxide solution (DMSO) to obtain the concentrations 500, 350, 250, $150,50 \mathrm{mg} / \mathrm{mL}$. DMSO solution was used as negative control, and the antibiotics Moxifloxacin 5 mcg and Gentamicin $10 \mathrm{mcg}$ as positive control $(30,32)$

\section{Determination of MIC}

MIC was measured by nutrient broth microdilution in microtitration plates containing 96 well $(33,34)$ 
with some modifications. The turbidity of prepared bacterial suspension was 0.5 McFarland $\left(10^{8}\right.$ $\mathrm{CFU} / \mathrm{mL}$ ). First, the dry extracts were dissolved in DMSO to obtain a concentration of $(350 \mathrm{mg} / \mathrm{mL})$ to be tested, then serial two-fold dilution was performed in a concentration range of 0.683 to 350 $\mathrm{mg} / \mathrm{mL}$. For each test batch, two control wells were prepared; negative control: nutrient broth medium (50 $\mu \mathrm{L})$ and bacterial suspension $(50 \mu \mathrm{L})$ in first well, positive control: plant extract $(50 \mu \mathrm{L})$ and bacterial suspension $(50 \mu \mathrm{L})$ in second well, all wells except the second were filled with the nutrient broth $(50 \mu \mathrm{L})$. Then, $50 \mu \mathrm{L}$ of plant extract at the highest concentration $(350 \mathrm{mg} / \mathrm{mL}$ ) were added to the third well and mixed, $50 \mu \mathrm{L}$ of mixture was taken for fourth well and so until serial decreasing concentrations were obtained in the rest of the wells. Then the wells were inoculated with bacterial suspension $50 \mu \mathrm{L}$, and the plates were incubated for $24 \mathrm{~h}$ at $37{ }^{\circ} \mathrm{C}$. Each well contained $100 \mu \mathrm{L}$ (final volume). After incubation, a solution $(20 \mu \mathrm{L})$ of 2,3,5-triphenyltetrazolium chloride (TTC) dissolved in water $(0.01 \%, w / v)$ was added to each well and plates were incubated for an additional $2 \mathrm{~h}$. Results were estimated visually by observing the color change from yellow to red, which is an indication of bacterial growth and determined MIC as lowest concentration in which it appeared medium in yellow (no red color) (33).

\section{Statistical Analysis}

SPSS software (version 22) was used by one-way ANOVA to analyze the data statistically. Pearson's correlation was used to determine the correlation between TPC, TFC and antioxidant activity. Data was considered statistically significant at minimum level of $\mathrm{P}<0.05$.

\section{RESULTS AND DISCUSSION}

Phytochemical qualitative screening of active chemical compounds

Pistacia atlantica extracts were distinguished by their high (very rich) of phenolic, tannin, and flavonoid contents and they were higher than and Pinus canariensis extracts (Table 1 ).

Saponins were found with a high content in $P$. canariensis aqueous extract, as a column of foam was formed more than $3 \mathrm{~cm}$ high and foam did not disappear after adding $\mathrm{HCl}$.

A high content of resin were found in ethanolic extract of $P$. canariensis, while it was absent in the aqueous extract of Pistacia atlantica, while alkaloids were absent in aqueous and ethanolic extracts of P. atlantica, and found only in a small amount in aqueous extract of Pinus canariensis. Coumarins and cardiac glycosides were not found in all extracts of both plants. For detection of active chemical compounds in P. atlantica leaves extracts; two studies in Libya and Armenia indicated that extracts contained phenols, flavonoids, and tannins. However, the study in Armenia showed the presence of coumarins, and this difference with our research may be due to the difference in the genetic combination of the plant, climatic conditions, and geographical location, in addition to the extraction methods and the quality of the solvents used $(35,36)$. No references were found concerned with phytochemical screening of Pinus canariensis extracts. Our results were however similar to many studies that indicated presence of phenols, saponins, and tannins in other species of the pine genus (37).

Table 1. Phytochemical screening of Pistacia atlantica and Pinus canariensis leaves extracts.

\begin{tabular}{|c|c|c|c|c|}
\hline \multirow{2}{*}{$\begin{array}{c}\text { Chemical } \\
\text { components }\end{array}$} & \multicolumn{2}{|c|}{ P. atlantica } & \multicolumn{2}{c|}{ P. canariensis } \\
\cline { 2 - 5 } & Aqueous & Ethanolic & Aqueous \\
extract & $\begin{array}{c}\text { Ethanolic } \\
\text { extract }\end{array}$ & - & + & - \\
\hline extract & - & - & - & - \\
\hline Cardiac glycosides & - & + & + & ++ \\
\hline Resins & - & +++ & +++ & ++ \\
\hline Tannins & +++ & ++ & ++ & ++ \\
\hline Phenols & +++ & +++ & + & + \\
\hline Flavonoids & ++ & ++ & +++ & - \\
\hline Saponins & + & - & - & - \\
\hline Coumarins & - & - & - & + \\
\hline
\end{tabular}

-: absence , + : presence in small quantities, ++ : presence in high quantities, +++ : presence in very high quantities.

Determination of yields, TPC, and TFC of $P$. atlantica and $P$. canariensis leaves extracts Yields of plant extracts differed according to extraction solvent used and plant species. The yields of ethanolic and aqueous extracts of Pistacia atlantica were $30.12 \% \pm 0.14$ and $24.20 \% \pm 0.08$, respectively, significantly higher than the yields of ethanolic and aqueous extracts of Pinus canariensis which amounted to $20.53 \% \pm 0.09$ and $15.77 \% \pm 0.04$, respectively (Table 2 ).

Results showed that TPC and TFC varies between both plants; $P$. atlantica extracts contained higher concentrations of phenols and flavonoids compared to $P$. canariensis extracts, phenolic contents of ethanolic extracts of $P$. atlantica and $P$. canariensis were $263.76 \pm 0.53$, and $40.52 \pm 0.58 \mathrm{mg} \mathrm{GAE} / \mathrm{g}$ 
Dw, respectively, while aqueous extracts reached $241.64 \pm 0.16$ and $30.11 \pm 0.37 \mathrm{mg} \mathrm{GAE} / \mathrm{g}$ Dw for the studied species, respectively. While the flavonoid contents of ethanolic extract of $P$. atlantica and $P$. canariensis reached $46.83 \pm 0.55$ and $9.80 \pm 0.12 \mathrm{mg} R E / g$ Dw, respectively, and the aqueous extract of $P$. atlantica and $P$. canariensis reached $31.81 \pm 0.26$ and $5.43 \pm 0.38$, respectively (Table 2 ).

Results of our study are consistent with many studies that prove that $P$. atlantica leaves extracts contain a good content of phenols and flavonoids at varying proportions, as one of the studies conducted in Tunisia showed TPC and TFC in ethanolic extract is higher than in aqueous, as TPC of ethanolic and aqueous extracts reached $68.23 \pm$ 0.8 and $20.07 \pm 0.2 \mathrm{mg} \mathrm{GAE} / \mathrm{g} \mathrm{Dw}$, respectively, while TFC reached $44 \pm 0.8$, and $15 \pm 0.2 \mathrm{mg} \mathrm{RE} / \mathrm{g}$ Dw for ethanolic and aqueous extracts, respectively (38).

TPC in aqueous, ethyl acetate, and n-butanol extracts of $P$. atlantica leaves in Algeria were $421.01 \pm 8.92,514.81 \pm 2.10$, and $376.34 \pm 3.43$ $\mathrm{mg} \mathrm{GAE} / \mathrm{g}$ Dw, respectively, while TFC were 44.51 $\pm 0.29,126.43 \pm 1.31$, and $103.77 \pm 1.07 \mathrm{mg} \mathrm{CE} / \mathrm{g}$ DW for previous extracts, respectively (39). One study was concerned in studying the effect of growing area, harvest time, and gender on phenolic and flavonoids compounds of P. atlantica leaves extracts. Results showed that phenols ranged between $79.00 \pm 13$ and $259 \pm 8 \mathrm{mg} \mathrm{GAE} / \mathrm{g}$ Dw, while flavonoids ranged between $0.65 \pm 0.10$ and $2.81 \pm 0.88 \mathrm{mg} \mathrm{QE} / \mathrm{g} \mathrm{DW}$ depending on the study period, phenolic contents of leaves is shown to decrease from spring to autumn; the content was affected by harvest time and growing region more than plant gender (male or female) (40).

No references were found concerning with TPC and TFC of P. canariensis extracts. Therefore, these results were compared with the results of research conducted on other species of pine genus, one of these studies determined TPC and TFC in aqueous, ethanol, and n-butanol extracts of Pinus roxburghii and Pinus wallichiana; phenolic contents of different solvents ranged $3.94 \pm 0.03,10.08 \pm$ 0.06 , and $8.55 \pm 0.28 \mathrm{mg} \mathrm{GAE} / \mathrm{g} \mathrm{Dw}$ respectively for Pinus roxburghii, while ranged $4.09 \pm 0.43$ and $4.06 \pm 1.12 \mathrm{mg}$ GAE/g Dw for ethanolic and butanol extracts respectively for Pinus wallichiana, while the phenolic contents were absent in aqueous extract for Pinus wallichiana (41). Results of the study conducted in Tunisia to determine content of phenols and flavonoids in ethanol extracts of leaves of 19 subspecies of Pinus nigra showed that total phenols ranged from $15.67 \pm$ 1.95 and $47.53 \pm 1.32 \mathrm{mg} \mathrm{GAE} / \mathrm{g} \mathrm{Dw}$, and amount of flavonoids varies from $1.69 \pm 0.32$ and 3.970 .17 $\mathrm{mg} \mathrm{RE} / \mathrm{g}$ Dw (42), while the study conducted in Romania showed a good content of phenols 78.22 $\pm 0.44 \mathrm{mg} \mathrm{GAE} / \mathrm{g}$ Dw and flavonoids $19.84 \pm 0.57$ $\mathrm{mg} \mathrm{CE} / \mathrm{g}$ DW for Pinus cembra needle extract (aqueous methanol extract 80\%) (20).

It should be noted that content of phenols and flavonoids in plant species in general is affected by different environmental factors characteristic of each geographical region, in addition to the difference in time of samples collection which in turn depended on growth rate, genetic diversity, different methods of storing and drying samples, and difference in extraction methods and solvent used in preparation of plant samples (39).

Table 2. Yields, TPC, and TFC in Pistacia atlantica and Pinus canariensis leaves extracts.

\begin{tabular}{|c|c|c|c|c|}
\hline \multirow[b]{2}{*}{ Plant species } & \multirow[b]{2}{*}{$\begin{array}{l}\text { Plant } \\
\text { extract }\end{array}$} & \multirow[b]{2}{*}{$\begin{array}{l}\text { Yields } \\
(\%)\end{array}$} & \multicolumn{2}{|c|}{ Contents } \\
\hline & & & $\begin{array}{l}\text { Total phenolic (TP) } \\
\text { (mg GAE/g Dw) }\end{array}$ & $\begin{array}{l}\text { Total Flavonoid (TF) } \\
\text { (mg RE/g Dw) }\end{array}$ \\
\hline \multirow{2}{*}{ P. atlantica } & Aqueous & $24.20 \pm 0.08$ & $241.64 \pm 0.16$ & $31.81 \pm 0.26$ \\
\hline & Ethanolic & $30.12 \pm 0.14$ & $263.76 \pm 0.53$ & $46.83 \pm 0.55$ \\
\hline \multirow{2}{*}{ P. canariensis } & Aqueous & $15.77 \pm 0.04$ & $30.11 \pm 0.37$ & $5.43 \pm 0.38$ \\
\hline & Ethanolic & $20.53 \pm 0.09$ & $40.52 \pm 0.58$ & $9.80 \pm 0.12$ \\
\hline
\end{tabular}

\section{Antioxidant activity}

Antioxidant activity was determined by calculating percentage of ability to DPPH radical scavenging as shown in Table 3. Results showed a good efficacy of plant extracts in scavenged DPPH radical, as antioxidant efficacy was arranged as follows: ethanolic extract of $P$. atlantica $90.27 \%$, aqueous extract of $P$. atlantica $81.77 \%$, ethanolic extract of $P$. canariensis $52.40 \%$, aqueous extract of $P$. canariensis $38.44 \%$, this arrangement corresponds to the order of total content of phenols and flavonoids in the studied plant extracts and confirms the role of these compounds as antioxidants. It was found that the concentration of ascorbic acid corresponding to the concentration of plant extracts and is able to record the same percentage of DPPH scavenging less than the concentration of the plant extracts by 11.42 19.04 double, as shown in Table 3. Therefore, both plants have good capacity in scavenging DPPH radical, and thus have antioxidant efficacy.

Phenolic compounds power as antioxidant is due to their ability to chelate metals, and their capacity as 
donors of hydrogen and electron from hydroxyl group allowing scavenging free radicals $(43,44)$, and corresponds to many studies that have shown that there was a strong correlation between content of phenols and antioxidant activity, confirming their responsibility as antioxidants (30, 45).
Results of the statistical study using Pearson's correlation showed a strong positive correlation 0.976 between efficiency of extracts in DPPH radical scavenging and their total phenolic contents, and their total flavonoid contents 0.974 , this confirms responsibility of these compounds for plant extracts efficiency as antioxidant.

Table 3. Antioxidant activity of $P$. atlantica and Pinus canariensis leaves extract.

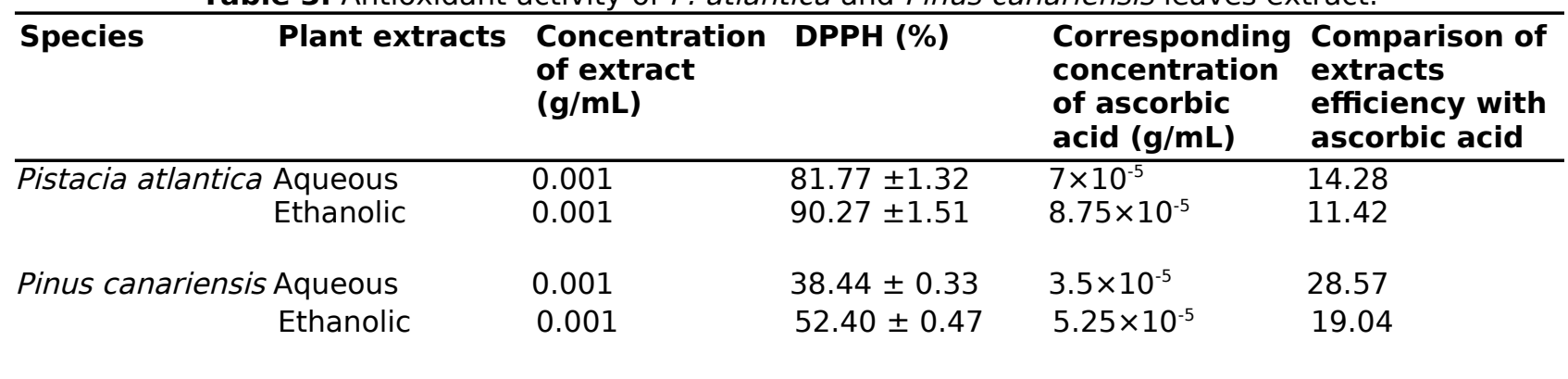

\section{Antibacterial activity}

Antibacterial activity of Pistacia atlantica

Table 4 and Figure 4 shows results of antibacterial activity of $P$. atlantica leaves extracts, ethanolic extract was found to be more effective and broadspectrum inhibition of bacterial growth compared to aqueous extract.

The highest inhibition zone diameter average of ethanolic extract was $14.83,19.33,20.96,23,26$, and $33.56 \mathrm{~mm}$ for E. coli, Klebsiella pneumoniae, Enterobacter cloacae, Proteus mirabilis, Staphylococcus aureus, and Shigella boydii, respectively, at $500 \mathrm{mg} / \mathrm{mL}$.

The lowest inhibition zone diameter average of ethanolic extract was 10.7, 10.9, 12.16, 18.5 and $26.0 \mathrm{~mm}$ for Pseudomonas aeruginosa, Proteus mirabilis, Enterobacter cloacae, Staphylococcus aureus, and Shigella boydii, respectively, at $50 \mathrm{mg} /$ $\mathrm{mL}$.

Ethanolic extract showed inhibitory activity of bacteria at all studied concentrations except for $E$. coli and Klebsiella pneumoniae at $50 \mathrm{mg} / \mathrm{mL}$.
The highest inhibition zone diameter average of aqueous extract was 11.0, 12.0, 13.25, 18.25, 24.65 and $29.25 \mathrm{~mm}$ for $E$. coli, Enterobacter cloacae, Proteus mirabilis, Staphylococcus aureus and Shigella boydii, respectively at $500 \mathrm{mg} / \mathrm{mL}$.

Aqueous extract didn't show any antibacterial activity at $50 \mathrm{mg} / \mathrm{mL}$ except of $E$. coli, Pseudomonas aeruginosa, and Shigella boydii, as inhibition zone diameter average was 5.5, 7.5 and $18.2 \mathrm{~mm}$, respectively.

While Klebsiella pneumoniae and Enterobacter cloacae didn't show sensitivity against aqueous extract except at concentrations 350 and $500 \mathrm{mg} /$ $\mathrm{mL}$, and equal efficacy of ethanolic and aqueous extracts against Pseudomonas aeruginosa were observed at a concentration of $500 \mathrm{mg} / \mathrm{mL}$, the inhibition zone diameter average were 16.83 and $16.74 \mathrm{~mm}$, respectively. The higher of extracts concentration increases their efficiency in bacteria. 
Table 4. Antibacterial activity (inhibition zone diameters average, $\mathrm{mm}$ ) of Pistacia atlantica leaves extracts.

\begin{tabular}{|c|c|c|c|c|c|c|}
\hline Bacterial Strains & $\begin{array}{l}\text { Concentrations } \mathrm{mg} / \\
\mathrm{mL}\end{array}$ & Aqueous Extract & Ethanolic Extract & Moxifloxacin 5 mcg & Gentamicin $10 \mathrm{mcg}$ & DMSO \\
\hline$\overline{\text { E.coli }}$ & $\begin{array}{l}50 \\
150 \\
250 \\
350 \\
500\end{array}$ & $\begin{array}{l}5.5 \pm 0.5 \\
6.75 \pm 0.25 \\
8 \pm 0.0 \\
8.5 \pm 0.5 \\
12 \pm 1\end{array}$ & $\begin{array}{l}0.0 \\
8.9 \pm 0.1 \\
10.43 \pm 0.40 \\
13.5 \pm 0.5 \\
14.83 \pm 0.28\end{array}$ & 0.0 & $16.5 \pm 0.5$ & 0 \\
\hline Klebsiella pneumoniae & $\begin{array}{l}50 \\
150 \\
250 \\
350 \\
500\end{array}$ & $\begin{array}{l}0.0 \\
0.0 \\
0.0 \\
6.5 \pm 0.5 \\
11 \pm 1\end{array}$ & $\begin{array}{l}0.0 \\
10.03 \pm 0.55 \\
13.33 \pm 0.76 \\
15.96 \pm 0.45 \\
19.33 \pm 0.57\end{array}$ & $31.5 \pm 0.5$ & $18.16 \pm 0.28$ & 0 \\
\hline Enterobacter cloacae & $\begin{array}{l}50 \\
150 \\
250 \\
350 \\
500\end{array}$ & $\begin{array}{l}0.0 \\
0.0 \\
0.0 \\
10.5 \pm 0.5 \\
13.25 \pm 0.75\end{array}$ & $\begin{array}{l}12.16 \pm 0.76 \\
15.03 \pm 0.25 \\
16.7 \pm 0.3 \\
18.5 \pm 0.5 \\
20.96 \pm 0.45\end{array}$ & $29 \pm 0.0$ & $17.75 \pm 0.25$ & 0 \\
\hline Shigella boydii & $\begin{array}{l}50 \\
150 \\
250 \\
350 \\
500\end{array}$ & $\begin{array}{l}18.2 \pm 0.8 \\
20.5 \pm 0.5 \\
21.5 \pm 0.5 \\
24.5 \pm 0.5 \\
29.25 \pm 0.75\end{array}$ & $\begin{array}{l}26 \pm 1 \\
28.5 \pm 0.5 \\
30.4 \pm 0.4 \\
31.25 \pm 0.25 \\
33.56 \pm 0.51\end{array}$ & $30.25 \pm 0.25$ & $25.75 \pm 0.75$ & 0 \\
\hline \multirow[t]{2}{*}{$\begin{array}{l}\text { Pseudomonas } \\
\text { aeruginosa }\end{array}$} & 50 & $7.5 \pm 0.5$ & $10.7 \pm 0.46$ & $22.75 \pm 0.75$ & $21.5 \pm 0.5$ & 0 \\
\hline & $\begin{array}{l}150 \\
250 \\
350 \\
500\end{array}$ & $\begin{array}{l}11.1 \pm 0.1 \\
12 \pm 0.0 \\
14.5 \pm 0.9 \\
16.74 \pm 0.8\end{array}$ & $\begin{array}{l}12.5 \pm 0.5 \\
13.8 \pm 0.28 \\
14.9 \pm 0.17 \\
16.83 \pm 0.65\end{array}$ & & & \\
\hline Proteus mirabilis & $\begin{array}{l}50 \\
150 \\
250 \\
350 \\
500\end{array}$ & $\begin{array}{l}0.0 \\
8.85 \pm 0.15 \\
12 \pm 1 \\
14.9 \pm 0.1 \\
18.25 \pm 0.25\end{array}$ & $\begin{array}{l}10.9 \pm 0.55 \\
14.5 \pm 0.5 \\
18.05 \pm 0.25 \\
20.13 \pm 0.40 \\
23 \pm 0.2\end{array}$ & 0.0 & 0.0 & 0 \\
\hline Staphylococcus aureus & $\begin{array}{l}50 \\
150 \\
250 \\
350\end{array}$ & $\begin{array}{l}0.0 \\
14.25 \pm 0.75 \\
17.4 \pm 0.2 \\
21.5 \pm 0.5\end{array}$ & $\begin{array}{l}18.5 \pm 0.5 \\
20.33 \pm 1.15 \\
22 \pm 1 \\
24 \pm 0.0\end{array}$ & $32 \pm 1$ & $10.25 \pm 0.25$ & 0 \\
\hline & 500 & $24.65 \pm 0.35$ & $26 \pm 0.2$ & & & \\
\hline
\end{tabular}




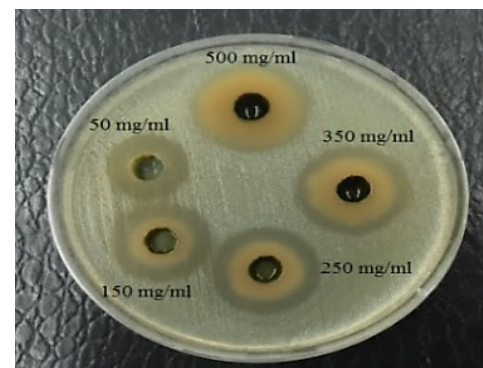

Staphylococcus aureus

Effect of ethanolic extracts

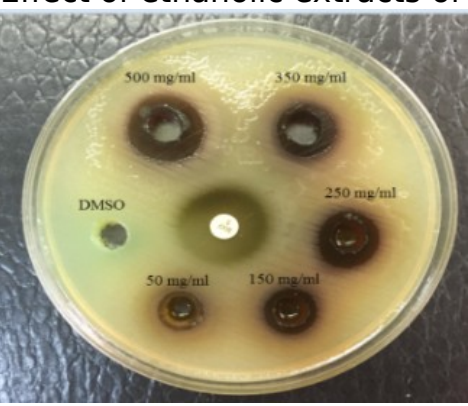

Pseudomonas aeruginosa

Effect of aqueous extracts of Pistacia atlantica against the

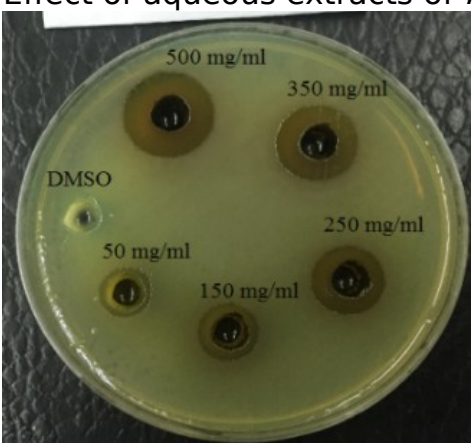

Pseudomonas aeruginosa

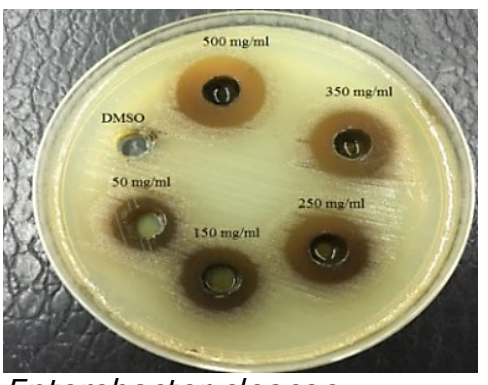

Enterobacter cloacae

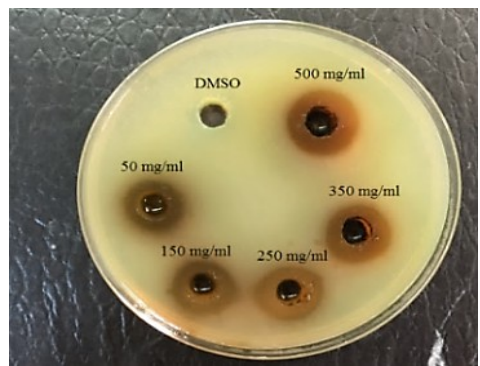

Pseudomonas aeruginosa

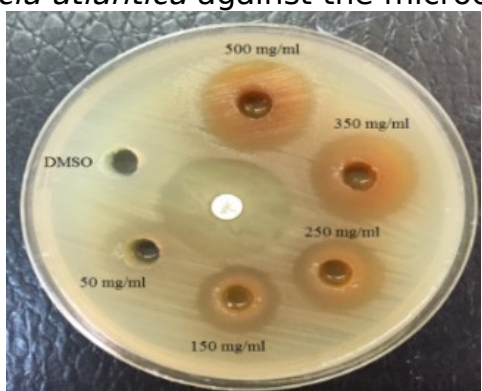

Staphylococcus aureus

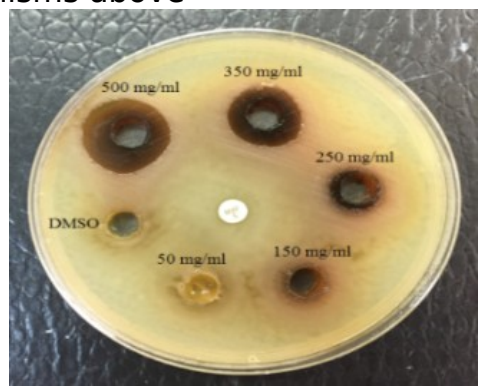

Proteus mirabilis

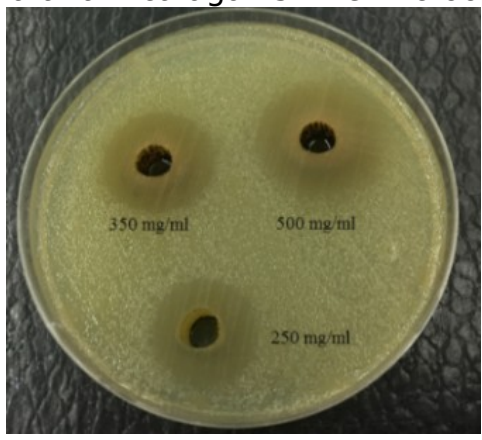

Shigella boydii

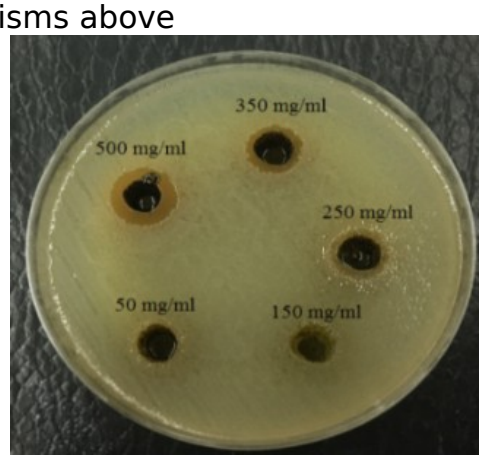

Klebsiella pneumoniae

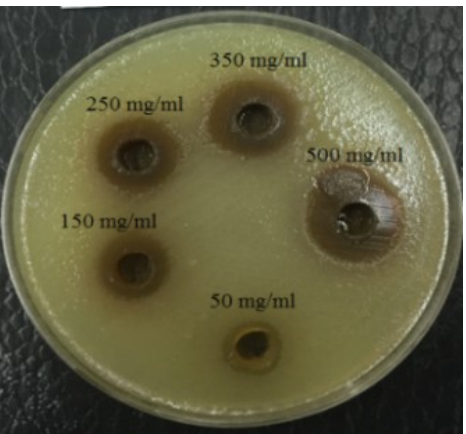

Pseudomonas aeruginosa

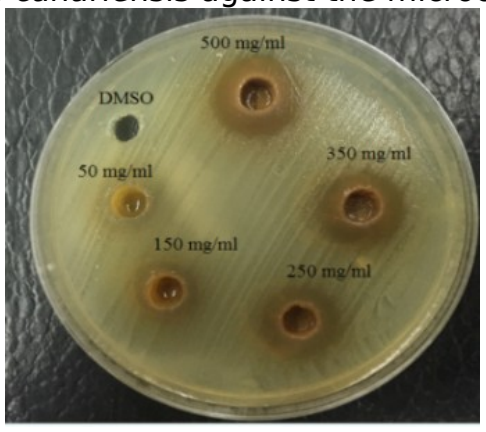

Staphylococcus aureus nisms above

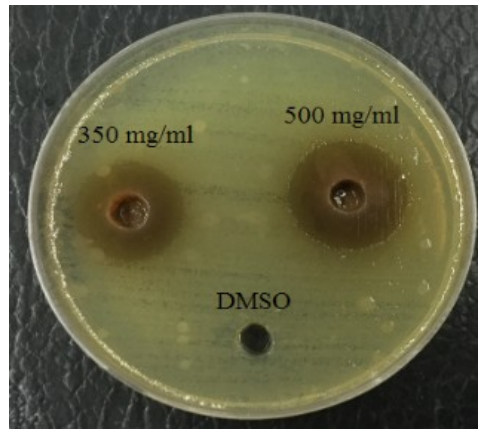

Shigella boydii

Effect of aqueous extracts of Pinus canariensis against the microorganisms above

Figure 4. Effect of different extracts of plants against bacteria.

Results are in agreement with one of studies that indicated efficacy of ethanolic extract against $E$. coli and Pseudomonas aeruginosa reached $14 \pm$ 0.9 and $16 \pm 0.3 \mathrm{~mm}$, respectively, while its results were less effective against Staphylococcus aureus which reached $14 \pm 1 \mathrm{~mm}$ (38). Also, efficacy of Pistacia atlantica extracts against Klebsiella pneumoniae was reported, which was recorded 13 $\pm 0.3 \mathrm{~mm}(46)$, and the results of this research did not agree with results (35); which did not show of $P$. atlantica leaves extract efficacy against Gram(-) bacteria Proteus vulgaris, and E. coli, but its efficacy against Staphylococcus saprophyticus was $8 \mathrm{~mm}$, and boiled distilled water extract of $P$. atlantica leaves showed an inhibitory effect for Streptococcus mutans and Streptococcus mitis 19 and $25 \mathrm{~mm}$, respectively, it was less effective against Streptococcus salivarius $5 \mathrm{~mm}$ (47). 


\section{Antibacterial activity of Pinus canariensis}

Results of Table 5 and Figure 4 showed that aqueous leaves extract was more effective than ethanolic extract in inhibition of Pseudomonas aeruginosa growth at all concentrations; the highest inhibition zone diameter average was 21 $\mathrm{mm}$ at a concentration of $500 \mathrm{mg} / \mathrm{mL}$. Ethanolic extract was the most effective in inhibition of $E$. coli, Klebsiella pneumoniae, Enterobacter cloacae, Proteus mirabilis, Staphylococcus aureus, and Shigella boydii; the highest inhibition zone diameter average was 14.16, 14.25, 15.5, 15.75, 22.75 and $29.56 \mathrm{~mm}$, respectively at concentration $500 \mathrm{mg} / \mathrm{mL}$.

Effect of aqueous and ethanolic extract on bacteria at concentration $50 \mathrm{mg} / \mathrm{mL}$ was not observed with exception of Pseudomonas aeruginosa and Shigella boydii.

The highest inhibition zone diameter average of aqueous extract for Staphylococcus aureus and Shigella boydii 18.5 and $23.4 \mathrm{~mm}$ respectively, and the lowest inhibition zone diameter average for Proteus mirabilis and E. coli 11.5 and $11.16 \mathrm{~mm}$ respectively, at $500 \mathrm{mg} / \mathrm{mL}$. Aqueous extract showed no effect in of Proteus mirabilis, Enterobacter cloacae, Klebsiella pneumoniae, and E. coli at concentrations of 50,150 and 250 $\mathrm{mg} / \mathrm{mL}$, inhibition zone diameter average didn't exceed $13 \mathrm{~mm}$ in Klebsiella pneumoniae and Enterobacter cloacae at concentration of 500 $\mathrm{mg} / \mathrm{mL}$, the effect of concentrations of extracts in bacteria growth was observed, as with increasing concentration, inhibition zone diameter increased. Compared with another studies, Pinus leaves extracts (water, ethanol, chloroform, and petroleum ether) showed efficacy against E. coli, Klebsiella pneumoniae, Salmonella typhi and Enterobacter aerogene, and better efficacy was of petroleum ether, chloroform, water, and ethanol extracts, inhibition zone diameter average didn't exceed $10 \mathrm{~mm}$ in water and ethanol extracts (22). Results of the research are in agreement with the study conducted in Iran, where efficacy of ethanolic leaves extract reached $70 \%$ against clinical isolates Pseudomonas aeruginosa and E. coli and Proteus vulgaris $17,15.66$ and $15.50 \mathrm{~mm}$, respectively, while it was less effective against Staphylococcus aureus, which was $16 \mathrm{~mm}$ (48).

Aqueous and ethanolic extract of Pinus leaves showed a lower effect against Pseudomonas aeruginosa with inhibition zone diameter average of 9.5 and $11 \mathrm{~mm}$, respectively, while our results show a better effect against this Pseudomonas aeruginosa, effect of ethanolic extract was absent on Salmonella typhi, and inhibition zone diameter average of aqueous extract against $\mathrm{E}$. coli was 11 $\mathrm{mm}$, and this is in agreement with the results of our study (49).
The difference in efficiency of these extracts compared to previous studies is due to various reasons, the most important of which are: difference of tested bacterial isolates, as a current study used multi-resistant bacteria, the difference in solvent and thus difference in quality of active compounds extracted, and the difference of extraction methods and concentration of used plant extract. Results showed that some plant extracts have better antibacterial activity than antibiotics Moxifloxacin $5 \mathrm{mcg}$ and Gentamicin 10 mcg, and DMSO solution didn't show any effect in tested bacteria, this confirms that DMSO doesn't have any antimicrobial activity, where plant extracts recorded significant $\quad(P<0.05)$ antibacterial activity between all bacterial inhibition zone diameters averages.

The efficiency of plant extracts is due to they contain many chemical compounds (secondary metabolites) that have antibacterial activity with different mechanisms; phenolic compounds interaction with bacterial cell wall (either they bind to outer membrane or peptidoglycan), and interaction with membrane proteins (increasing membrane permeability). In addition to their ability to inhibition of biofilm formation, and to inhibition of bacterial enzymes, thus preventing bacterial growth. Found that Gram(-) bacteria are more resistant than $\operatorname{Gram}(+)$ bacteria to phenolic compounds actions; due to differences in cell wall structure, as outer membrane of Gram(-) bacteria is mainly composed of lipopolysaccharides (LPS) $(50,51,52)$. It should be noted that this antimicrobial activity is not only related to quantities of phenolic compounds but also related to structure of these compounds (site(s) and number of hydroxyl groups on phenol group) (53). Nonspecific interactions of flavonoids can induce structural changes in properties of membrane and its can cause metabolic dysfunction and finally lead to bacterial death. Moreover, they are inhibit of synthesis of cell envelope, nucleic acid, and ATP, in addition to their ability to inhibition of bacterial toxins (54). Tannins may be related to their ability to inactivate microbial adhesins, have a role on inhibition of enzymes essential to metabolism process; such as proteolytic macerating enzymes, and their ability to inactivate cell envelope transport proteins, and their ability to complex with cell wall, while, saponins cause cell walls permeability disruption, and thus cause toxicity in cell (53).

\section{Determination of MIC for $P$. atlantica and $P$. canariensis extracts}

MIC of aqueous extract of $P$. atlantica ranged from $10.937 \mathrm{mg} / \mathrm{mL}$ for Proteus mirabilis to $43.75 \mathrm{mg} / \mathrm{mL}$ for Pseudomonas aeruginosa, while ethanolic extract of $P$. atlantica ranged from $5.468 \mathrm{mg} / \mathrm{mL}$ for E. coli, Enterobacter cloacae, Shigella boydii, Proteus mirabilis, and Staphylococcus aureus to $10.937 \mathrm{mg} / \mathrm{mL}$ for Klebsiella pneumoniae and Pseudomonas aeruginosa, the aqueous extract of 
$P$. canariensis ranged from $21.875 \mathrm{mg} / \mathrm{mL}$ for $E$. coli, Shigella boydii, and Staphylococcus aureus to $43.75 \mathrm{mg} / \mathrm{mL}$ for Klebsiella pneumoniae, Enterobacter cloacae, Pseudomonas aeruginosa, and Proteus mirabilis, while ethanolic extract of $P$. canariensis ranged from $5.468 \mathrm{mg} / \mathrm{mL}$ for Staphylococcus aureus to $21.875 \mathrm{mg} / \mathrm{mL}$ for Klebsiella pneumoniae, Enterobacter cloacae, and Pseudomonas aeruginosa as shown in Table 6 . Compared with the Tunisian study, MIC of ethanolic extract of $P$. atlantica leaves reached $25 \mathrm{mg} / \mathrm{mL}$ for E. coli, $6.25 \mathrm{mg} / \mathrm{mL}$ for Pseudomonas aeruginosa and 12.5 for Staphylococcus aureus and Salmonella typhimurium, the values obtained in the current study are better for $E$. coli and Staphylococcus aureus (38). MIC of ethanolic extract of pinus leaves reached $7.29 \mathrm{mg} / \mathrm{mL}$ for Pseudomonas aeruginosa, $9.37 \mathrm{mg} / \mathrm{mL}$ for Staphylococcus aureus, $16.66 \mathrm{mg} / \mathrm{mL}$ for E.coli and Proteus vulgaris, results of MIC in the current study are better for $\mathrm{E}$. coli and Staphylococcus aureus (48). Difference in these values can be explained by different sensitivity and resistance of tested bacterial isolates, and difference in environment and genetic combination of plant.

\section{CONCLUSION}

The current study showed of $P$. atlantica extracts gave a higher yield than of $P$. canariensis extracts. Phytochemical compounds (tannins, phenols, and flavonoids) were found in the extracts of both plants, while saponins were present in the aqueous extracts only. $P$. atlantica extracts contained a higher content of phenols and flavonoids compared to $P$. canariensis extracts, while all extracts had antioxidant activity which could be a suitable alternative to synthetic antioxidants, and all extracts showed antibacterial activity, but not all concentrations showed bioactivity against some of tested bacterial species, it was found that antibacterial activity increases with increasing concentration of plant extracts, and Shigella boydii was the most sensitive against of extracts of both plants, therefore, more studies are needed to isolate bioactive compounds from both plants extracts, which will help in development of medicinal and pharmaceutical products. 
Table 5. Antibacterial activity (inhibition zone diameters average, $\mathrm{mm}$ ) of Pinus canariensis leaves extracts.

\begin{tabular}{|c|c|c|c|c|c|c|}
\hline Bacterial Strains & $\begin{array}{l}\text { Concentrations } \mathrm{mg} / \\
\mathrm{mL}\end{array}$ & Aqueous Extract & Ethanolic Extract & $\begin{array}{l}\text { Moxifloxacin (5 } \\
\text { mcg) }\end{array}$ & $\begin{array}{l}\text { Gentamicin (10 } \\
\text { mcg) }\end{array}$ & DMSO \\
\hline \multirow[t]{5}{*}{$\overline{E . ~ c o l i}$} & 50 & 0.0 & 0.0 & 0.0 & $0.5 \pm 16.5$ & 0 \\
\hline & & 0.0 & 0.0 & & & \\
\hline & 250 & 0.0 & $9.75 \pm 0.25$ & & & \\
\hline & 350 & 0.0 & $12.7 \pm 0.3$ & & & \\
\hline & 500 & $11.16 \pm 0.76$ & $14.16 \pm 0.76$ & & & \\
\hline \multirow[t]{5}{*}{ Klebsiella pneumoniae } & 250 & 0.0 & 0.0 & $31.5 \pm 0.5$ & $18.16 \pm 0.28$ & 0 \\
\hline & 150 & 0.0 & 0.0 & & & \\
\hline & 250 & 0.0 & $10.5 \pm 0.5$ & & & \\
\hline & 350 & $11.75 \pm 0.25$ & $12.13 \pm 0.23$ & & & \\
\hline & 500 & $12.75 \pm 0.25$ & $14.25 \pm 0.25$ & & & \\
\hline \multirow[t]{5}{*}{ Enterobacter cloacae } & 50 & 0.0 & 0.0 & $29 \pm 0.0$ & $17.75 \pm 0.25$ & 0 \\
\hline & 150 & 0.0 & $9.5 \pm 0.5$ & & & \\
\hline & 250 & 0.0 & $12.03 \pm 0.55$ & & & \\
\hline & 350 & $8.66 \pm 0.76$ & $13.25 \pm 0.25$ & & & \\
\hline & 500 & $13 \pm 1$ & $15.5 \pm 0.5$ & & & \\
\hline \multirow[t]{4}{*}{ Shigella boydii } & 50 & $14.1 \pm 0.36$ & $19.25 \pm 0.25$ & $30.25 \pm 0.25$ & $25.75 \pm 0.75$ & 0 \\
\hline & 150 & $17.66 \pm 0.57$ & $21.3 \pm 0.3$ & & & \\
\hline & 250 & $19.5 \pm 0.5$ & $23 \pm 0.0$ & & & \\
\hline & 350 & $20.6 \pm 0.4$ & $24.66 \pm 0.57$ & & & \\
\hline
\end{tabular}


Alhajali O, Ali-Nizam A. JOTCSA. 2021; 8(2): 403-418.

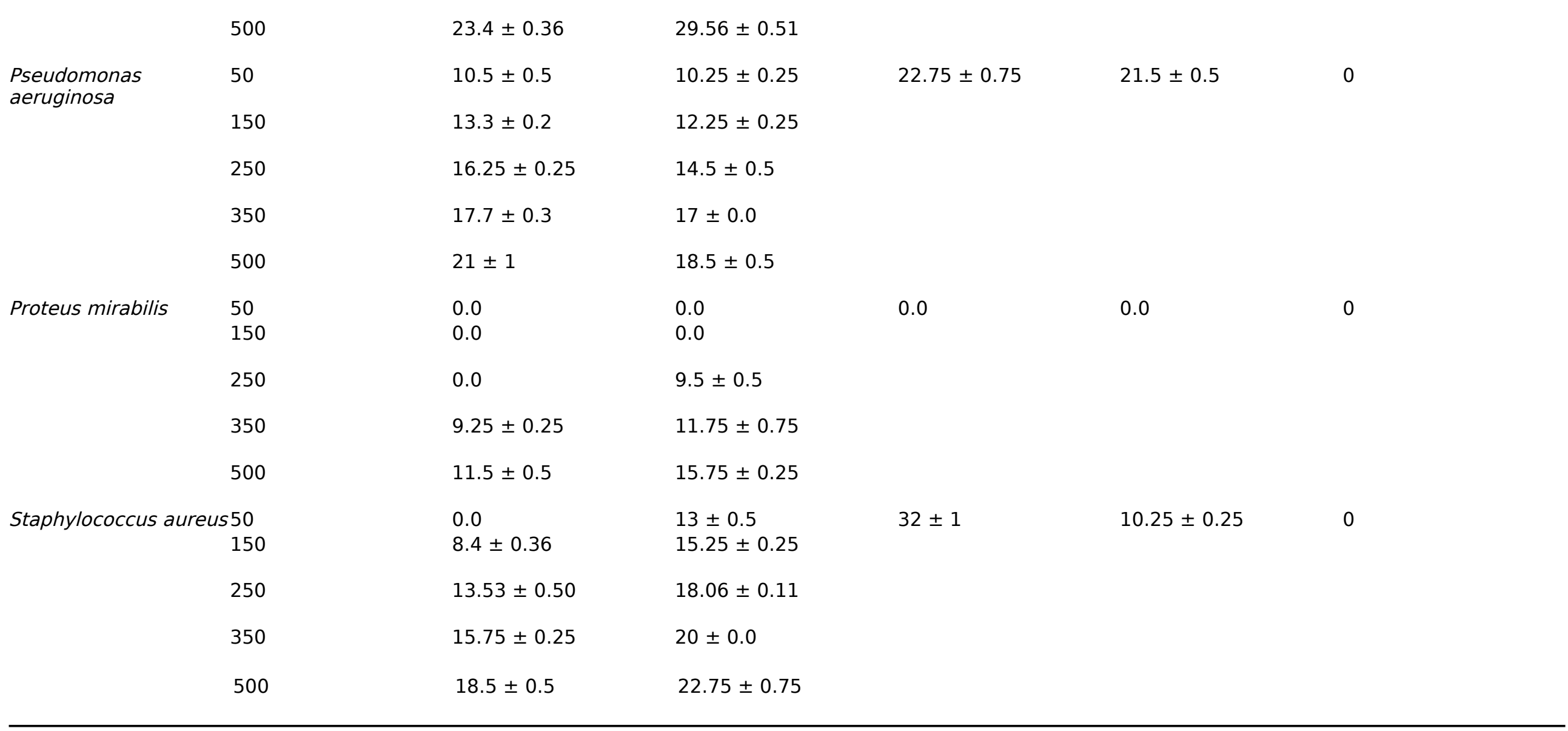


Table 6. MIC of Pistacia atlantica and Pinus canariensis leaves extracts.

\begin{tabular}{ccccc}
\hline \multirow{2}{*}{ Bacterial strains } & \multicolumn{2}{c}{$\boldsymbol{P}$. atlantica } & \multicolumn{2}{c}{$\boldsymbol{P . \text { canariensis }}$} \\
\cline { 2 - 5 } & $\begin{array}{c}\text { Aqueous } \\
\text { extract } \mathbf{~ m g / m L}\end{array}$ & $\begin{array}{c}\text { Ethanolic } \\
\text { extract } \mathbf{~ m g / m L}\end{array}$ & $\begin{array}{c}\text { Aqueous } \\
\text { extract } \mathbf{~ m g / m L}\end{array}$ & $\begin{array}{c}\text { Ethanolic } \\
\text { extract } \mathbf{~ m g} / \mathbf{m L}\end{array}$ \\
\hline $\begin{array}{c}\text { E. coli } \\
\text { Klebsiella }\end{array}$ & 21.875 & 5.468 & 21.875 & 10.937 \\
pneumoniae & 21.875 & 10.937 & 43.75 & 21.875 \\
$\begin{array}{c}\text { Enterobacter cloacae } \\
\text { Shigella boydii }\end{array}$ & 21.875 & 5.468 & 43.75 & 21.875 \\
$\begin{array}{c}\text { Pseudomonas } \\
\text { aeruginosa }\end{array}$ & 21.875 & 5.468 & 21.875 & 10.937 \\
$\begin{array}{c}\text { Proteus mirabilis } \\
\text { Staphylococcus }\end{array}$ & 10.937 & 10.937 & 43.75 & 21.875 \\
aureus & 21.875 & 5.468 & 43.75 & 10.937 \\
\hline
\end{tabular}

\section{REFERENCES}

1. Sarker SD. Pharmacognosy in modern pharmacy curricula. Pharmacognosy magazine. 2012 Apr;8(30):91. DOI: 10.4103/0973-1296.96545.

2. Bahmani $M$, Saki $K$, Asadbeygi $M$, Adineh $A$, Saberianpour S, Rafieian-Kopaei M, Bahmani $F$, Bahmani E. The effects of nutritional and medicinal mastic herb (Pistacia atlantica). Journal of Chemical and Pharmaceutical Research. 2015(1):646-53.

3. World Health Organization. WHO guidelines on safety monitoring of herbal medicines in pharmacovigilance systems. World Health Organization; 2004.

4. Ali - Nizam A, Hussain M. Prevalence, Antibiotic resistance of Staphylococcus aureus, CNS and determination of MRSA, MRCNS strains in clinical samples. Tishreen University Journal for Research and Scientific Studies-Biological Sciences Series. 2016; 38(1):167-80.

5. Lopez-Romero JC, González-Ríos H, Borges A, Simões M. Antibacterial effects and mode of action of selected essential oils components against Escherichia coli and Staphylococcus aureus. Evidence-Based Complementary and Alternative Medicine. 2015 Jan 1;2015. doi: 10.1155/2015/795435.

6. Krishnamurthy V, Chandrashekar S, Kumar M, Sagar D. Efficiency of Crude Extract of Ocimum sanctum, Ocimum gratissimum and Ocimum basilicum leaves against bacterial pathogens. Int. J. Curr. Microbiol. App. Sci. 2018; 7(4): 2609-15.

7. Layqa M, Ali-Nizam A, Alqadi I. Antibacterial Activity of White and Blue Wild Myrtle Parts Extracts Against Staphylococcus aureus and Staphylococcus epidermidis. Egypt. J. Microbiol. 2015; 50, 17- 29.

8. ASSIS FV, Siqueira FL, Goncalves IE, Lacerda RP, Nascimento RA, Araujo SG, Andrade JT, Herrera K, Lima LA, Ferreira J. Antibacterial activity of
Lamiaceae plant extracts in clinical isolates of multidrug-resistant bacteria. Anais da Academia Brasileira de Ciências. 2018 Apr;90(2):1665-70. Doi: 10.1590/0001-3765201820160870.

9. Mahjoub F, Rezayat KA, Yousefi M, Mohebbi M, Salari R. Pistacia atlantica Desf. A review of its traditional uses, phytochemicals and pharmacology. Journal of medicine and life. 2018 Jul;11(3):180. Doi: 10.25122/jml-2017-0055.

10. Mecherara-Idjeri S, Hassani A, Castola V, Casanova J. Composition of leaf, fruit and gall essential oils of Algerian Pistacia atlantica Desf. Journal of Essential Oil Research. 2008 May $1 ; 20(3): 215-9$.

10.1080/10412905.2008.9699995.

11. Bozorgi M, Memariani Z, Mobli M, Salehi Surmaghi $M H$, Shams-Ardekani MR, Rahimi R. Five Pistacia species ( $P$. vera, $P$. atlantica, $P$. terebinthus, $P$. khinjuk, and $P$. lentiscus): a review of their traditional uses, phytochemistry, and pharmacology. The Scientific World Journal. 2013 Jan 1;2013. Doi: 10.1155/2013/219815.

12. Benhammou N, Bekkara FA, Panovska TK. Antioxidant and antimicrobial activities of the Pistacia lentiscus and Pistacia atlantica extracts. African Journal of Pharmacy and Pharmacology. 2008 Apr 30;2(2):022-8. Doi: 10.5897/AJPP.9000056

13. Asma A, Boumediene T, Mohammed B, Nourelhouda T, Mebrouka B. Antibacterial activity and physicochemical characteristics of Pistacia atlantica extracts. Der Pharma Chemica. 2016; 8(12): 162-68.

14. Shialy Z, Zarrin M, Nejad BS, Naanaie SY. In vitro antifungal properties of Pistacia atlantica and olive extracts on different fungal species. Current medical mycology. 2015 Dec;1(4):40. Doi 10.18869/acadpub.cmm.1.4.40.

15. Karimi A, Moradi MT, Gafourian A. In vitro antiadenovirus activity and antioxidant potential of 
Pistacia atlantica Desf. leaves. Research Journal of Pharmacognosy (RJP). 2020;7(2).

16. Hajjaj G, Chakour R, Bahlouli A, Tajani M, Cherrah Y, Zellou A. Evaluation of CNS activity and anti-inflammatory effect of Pistacia atlantica desf. essential oil from Morocco. Pharm Chem J. 2018;5:86-94.

17. Navascués, M. Genetic diversity of the endemic Canary Island pine tree, Pinus canariensis (Doctoral dissertation), University of East Anglia, Norwich. 2005.

18. Pfeifhofer HW. Composition of the essential oil of Pinus canariensis Sweet ex Sprengel. Flavour and fragrance journal. 2000 Jul;15(4):266-70. Doi: 10.1002/1099-1026(200007/08)15:4<266::AIDFFJ908>3.0.CO;2-E.

19. Ioannou E, Koutsaviti A, Tzakou O, Roussis V. The genus Pinus: a comparative study on the needle essential oil composition of 46 pine species. Phytochemistry Reviews. 2014 Dec 1;13(4):741-68. Doi: 10.1007/s11101-014-9338-4.

20. Apetrei CL, Tuchilus C, Aprotosoaie AC, Oprea A, Malterud KE, Miron A. Chemical, antioxidant and antimicrobial investigations of Pinus cembra L. bark and needles. Molecules. 2011 Sep;16(9):7773-88. DOI:10.3390/molecules16097773.

21. Kwak CS, Moon SC, Lee MS. Antioxidant, antimutagenic, and antitumor effects of pine needles (Pinus densiflora). Nutrition and cancer. 2006 Nov 1;56(2):162-71. Doi: $10.1207 /$ s15327914nc5602_7.

22. Bissa, S, Bohra, A. Antibacterial Potental of Three Naked-Seeded (Gymnosperm) Plants, Microbiology Laboratory, J. N. V. University, India, Natural Product Radiance. 2008; 7(5): 420-25.

23. Teresa $M$, Bandiola $B$. Extraction and qualitative phytochemical screening of medicinal plants: A brief summary. International Journal of Pharmacy. 2018;8(1):137-43.

24. Archana $P$, Samatha $T$, Mahitha $B$, Chamundeswari NR. Preliminary phytochemical screening from leaf and seed extracts of Senna alata L. Roxb-an ethno medicinal plant. Int J Pharm Biol Res. 2012;3:82-9.

25. Sati SC, Kumar P. Assessment of Himalayan juniper, Juniperus squamata buch-ham ex $d$. don for phytochemical screening and antimicrobial potential against some infection causing pathogens. World J Pharmaceut Res. 2015 Jul 23;4:998-1011.

26. Olabiyi TI, Oyedunmade EE, Ibikunle GJ, Ojo OA, Adesina GO, Adelasoye KA, Ogunniran TA. Chemical composition and bio-nematicidal potential of some weed extracts on Meloidogyne incognita under laboratory conditions. Plant Sciences Research. 2008;1(2):30-5. Doi:pares.2008.30.35.

27. Savithramma N, Rao ML, Suhrulatha D. Screening of medicinal plants for secondary metabolites. Middle-East Journal of Scientific Research. 2011;8(3):579-84.

28. Shaghaghi $M$, Manzoori JL, Jouyban $A$ Determination of total phenols in tea infusions, tomato and apple juice by terbium sensitized fluorescence method as an alternative approach to the Folin-Ciocalteu spectrophotometric method. Food chemistry. 2008 May 15;108(2):695-701. Doi: 10.1016/j.foodchem.2007.11.008.

29. AlHafez M, Kheder F, AlJoubbeh M. Polyphenols, flavonoids and (-)-epigallocatechin gallate in tea leaves and in their infusions under various conditions. Nutrition \& Food Science. 2014 Sep 2; 44(5): 455-63. Doi: 10.1108/NFS-10-2013-0119.

30. Sharma A, Goyal R, Sharma L. Potential biological efficacy of Pinus plant species against oxidative, inflammatory and microbial disorders. BMC complementary and alternative medicine. 2015 Dec 1;16(1):35. Doi: 10.1186/s12906-0161011-6.

31. Sarikurkcu C, Arisoy K, Tepe B, Cakir A, Abali G, Mete E. Studies on the antioxidant activity of essential oil and different solvent extracts of Vitex agnus castus $L$. fruits from Turkey. Food and Chemical Toxicology. 2009 Oct 1;47(10):2479-83. Doi: 10.1016/j.fct.2009.07.005.

32. Perez C. Antibiotic assay by agar-well diffusion method. Acta Biol Med Exp. 1990;15:113-5.

33. Langfield RD, Scarano FJ, Heitzman ME, Kondo $M$, Hammond GB, Neto CC. Use of a modified microplate bioassay method to investigate antibacterial activity in the Peruvian medicinal plant Peperomia galioides. Journal of ethnopharmacology. 2004 Oct 1;94(2-3):279-81. Doi: 10.1016/j.jep.2004.06.013.

34. Balouiri M, Sadiki M, Ibnsouda SK. Methods for in vitro evaluating antimicrobial activity: A review. Journal of pharmaceutical analysis. 2016 Apr 1;6(2):71-9. Doi: 10.1016/j.jpha.2015.11.005.

35. Edrah S, Alafid F, Kumar A. Preliminary phytochemical screening and antibacterial activity of Pistacia atlantica and Prunus persica plants of Libyan origin. International Journal of Science and Research. 2013;6:14.

36. Khudoyan SH, Karapetyan LG, Zakaryan NH, Antonyan AA, Nanagulyan SG. Chemical composition and bioactivity of extracts from leaves 
and branches of Armenian Pistacia Atlantica Desf. Chemistry and Biology, 2018 Apr 15; 52(1): 37-44.

37. Akhtar N, Mirza B. Phytochemical analysis and comprehensive evaluation of antimicrobial and antioxidant properties of 61 medicinal plant species. Arabian Journal of Chemistry. 2018 Dec $1 ; 11(8): 1223-35$.

10.1016/j.arabjc.2015.01.013.

38. Rigane G, Ghazghazi H, Aouadhi C, Ben Salem R, Nasr Z. Phenolic content, antioxidant capacity and antimicrobial activity of leaf extracts from Pistacia atlantica. Natural product research. 2017 Mar 19;31(6):696-9. Doi:

10.1080/14786419.2016.1212035.

39. Benamar $\mathrm{H}$, Marouf $\mathrm{A}$, Bennaceur $\mathrm{M}$. Phytochemical composition, antioxidant and acetylcholinesterase inhibitory activities of aqueous extract and fractions of Pistacia atlantica subsp. atlantica from Algeria. Journal of Herbs, Spices \& Medicinal Plants. 2018 Jul 3;24(3):229-44. Doi: 10.1080/10496475.2018.1446204.

40. Ben Ahmed Z, Yousfi M, Viaene J, Dejaegher B, Demeyer $K$, Mangelings D, Vander Heyden $Y$. Seasonal, gender and regional variations in total phenolic, flavonoid, and condensed tannins contents and in antioxidant properties from Pistacia atlantica ssp. leaves. Pharmaceutical biology. 2017 Jan 1;55(1):1185-94. Doi: 10.1080/13880209.2017.1291690.

41. Maimoona A, Naeem I, Saddiqe Z, Ali N. Analysis of total flavonoids and phenolics in different fractions of bark and needle extracts of Pinus roxburghii and Pinus wallichiana. Journal of Medicinal Plants Research. 2011 Oct 9;5(21):521620. Doi: 10.5897/JMPR.9000082.

42. Fkiri S, Mezni F, Ouarghi A, Ghazghazi $H$, KHOUJA ML, Khaldi A, Nasr Z. Variability of phenolic compounds and antioxidant efficacy in needles extracts of Pinus nigra Arn. Journal of new sciences, Agriculture and Biotechnology 2018; 53 (1): 352835.

43. Amri O, Elguiche $R$, Tahrouch S, Zekhnini A, Hatimi A. Antifungal and antioxidant activities of some aromatic and medicinal plants from the southwest of Morocco. Journal of chemical and pharmaceutical Research. 2015;7(7):672-8.

44. Hatamnia AA, Rostamzad A, Hosseini M, Abbaspour N, Darvishzadeh R, Malekzadeh $P$, Aminzadeh BM. Antioxidant capacity and phenolic composition of leaves from 10 Bene (Pistacia atlantica subsp. kurdica) genotypes. Natural product research. 2016 Mar 3;30(5):600-4.

45. Malekzadeh $P$, Hatamnia AA, Nourollahi K. Total phenolic content and antioxidant activity of fruit and leaf of Bene (Pistacia atlantica subsp. Kurdica)
Ilam province. in Plant Physiology. 2015 Oct

1;6(1):1543-9. Doi:

10.1080/14786419.2015.1028060

46. Mahdavi Meymand Z, Moshafi MH, Forotanfar $\mathrm{H}$. Antibacterial activity of metanolic extract of 12 herbal species on 6 bacterial strains using cylinderplate method. Journal of Rafsanjan University of Medical Sciences. 2009 Dec 10;8(3):227-38.

47. Roozegar MA, Jalilian FA, Havasian MR, Panahi J, Pakzad I. Antimicrobial effect of Pistacia atlantica leaf extract. Bioinformation. 2016;12(1):19. Doi: $10.6026 / 97320630012019$.

48. Nozohour $\mathrm{Y}$, Golmohammadi R, Mirnejad R, Moghaddam MM, Fartashvand M.Comparison of Antibacterial Activities of Walnut (Juglans regia L.) and Pine (Pinus halepensis Mill.) Leaves Alcoholic Extracts against Bacteria Isolated from Burn Wound Infections, Acta Microbiologica Hellenica. 2019; 64(2): 47-56.

49. AL-Shekhany YN, Al-Juboori MK. Antibacterial activity of ethanol and aqueous extracts of some Perennial plants against three gram negative pathogenic bacteria from Koya city-Kurdistan Region-Northern Iraq. Diyala Journal For Pure Science. 2017;13(3-part 1):135-49.

50. Cowan MM. Plant products as antimicrobial agents. Clinical microbiology reviews. 1999 Oct 1;12(4):564-82. Doi : 10.24237/djps.1303.224B.

51. Sabbineni, J. Phenol-An effective antibacterial Agent, Research \& Reviews. Journal of Medicinal \& Organic Chemistry. 2016 ; 3(2): 182-91.

52. Papuc C, Goran GV, Predescu CN, Nicorescu V, Stefan G. Plant polyphenols as antioxidant and antibacterial agents for shelf-life extension of meat and meat products: Classification, structures, sources, and action mechanisms. Comprehensive Reviews in Food Science and Food Safety. 2017 Nov;16(6):1243-68. Doi: 10.1111/15414337.12298.

53. Omojate Godstime C, Enwa Felix O, Jewo Augustina O, Eze Christopher O. Mechanisms of antimicrobial actions of phytochemicals against enteric pathogens-a review. J Pharm Chem Biol Sci. 2014 Aug;2(2):77-85.

54. Górniak I, Bartoszewski R, Króliczewski J. Comprehensive review of antimicrobial activities of plant flavonoids. Phytochemistry Reviews. 2019 Feb 15;18(1):241-72. Doi: 10.1007/s11101-0189591-z. 